\title{
Foundation phase teacher provision by public higher education institutions in South Africa
}

\begin{abstract}
The study reported in this paper investigated foundation phase teacher provision by the public universities in South Africa, with a view to carefully and accurately determine the extent to which foundation phase teacher provision matched national as well as provincial needs. The study draws on data obtained through a survey of teacher provision at the public higher education institutions (HEIs), conducted by the national Department of Education (DoE) in 2009, as well as from data relating to teacher education qualifications and programmes in the Higher Education Management Information System (HEMIS).

The study confirmed perceptions that the number of new foundation phase teachers being produced by the public higher education institutions (HEls) falls short of national and provincial needs, and that the provision of African language foundation phase teachers is particularly problematic, especially in the context of mother-tongue instruction in the early years.
\end{abstract}

Keywords: teacher supply and demand; foundation phase; teacher education; mothertongue; African languages; early childhood education; higher education institutions

Whitfield Green, Department of Higher Education and Training. E-mail: Green.W@dhet.gov.za. Diane Parker, Department of Higher Education and Training. E-mail: Parker.D@dhet.gov.za. Roger Deacon, University of KwaZulu-Natal.E-mail: deacon@ukzn.ac.za.

Graham Hall, University of the Witwatersrand.E-mail: Graham.Hall@wits.ac.za.

South African Journal of Childhood Education | 2011 1(1): 109-122 |ISSN: 2223-7674 | ৫ UJ
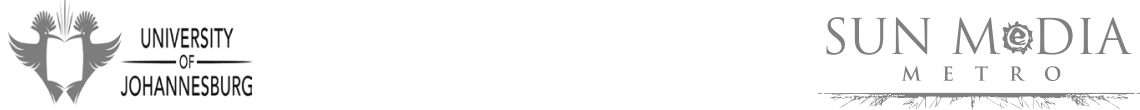


\section{Foundation phase education in South Africa}

There is a real interest, in all spheres of public life in South Africa, in early school education. Learning opportunities in the formative years impact significantly on further learning and development. High quality early care and education is of particular benefit to children from disadvantaged backgrounds (Ackerman, 2005). Mourshed and Barber (2007) report on best practices of highly successful schools and what they have in common is good early education and teacher education. A 2007 United Nations Educational Scientific and Cultural Organisation (UNESCO) report on early childhood education highlighted that:

Young children's experiences in the first years of life - well before they begin school - create the foundation for subsequent learning. Although early childhood is a period of great potential for human growth and development, it is also a time when children are especially fragile and vulnerable (UNESCO, 2007).

This certainly appears to be the case in South Africa, where the majority of children experience severe shortfalls in the kind of learning experiences that they are exposed to in the years before they enter formal schooling. In many cases, shortfalls happen when learners enter formal schooling are compounded by the quality of the learning experience in schools.

In 2007, the Department of Education conducted a second cycle of Systemic Evaluations at the foundation phase (Grade 3 ) level. This was a replica study of a similar evaluation conducted in 2001, and involved the assessment of a random sample of 53972 Grade 3 learners from 2327 primary schools across South Africa. The second study showed a positive increase in performance in Literacy from an average score of $30 \%$ in 2001 to $36 \%$ in 2007 and in Numeracy from an average score of $30 \%$ in 2001 to $36 \%$ in 2007 (DoE, 2008). A caveat is essential here; other documents emanating from the Department of Education report different figures with regard to literacy (cf. DoE, 2003a: ix, 32, 51; DoE, 2003b; DoE, 2009a: 77-8; DBE, 2010: 34-5). All such documentation agrees, however, that learner performance in both Literacy and Numeracy is abysmal and must be drastically improved.

In reflecting on the results of the 2007 evaluation in an opening address to the National Foundation Phase Conference (DoE, 2008), the then Minister of Education, Naledi Pandor, noted the increase in performance, but expressed the sentiment that the "scores are still unacceptably low". The Minister also pointed out that learner performance in the foundation phase appeared to vary in relation to the language of instruction, and according to the school that learners attended. In particular, it was noted that African language mother-tongue speakers scored significantly lower on the assessments in comparison to their English-speaking and Afrikaans-speaking peers. For example, the average Literacy scores for English and Afrikaans learners was $48 \%$ and $49 \%$ respectively, while for both Siswati and Tshivenda learners the average Literacy score was $26 \%$.

The Systemic Evaluations demonstrated clearly that significant inequality in foundation phase education provision exists in the system. It is not unreasonable to 
think that some of this must be related to the teachers. Many of the teachers who teach young children have not, in fact, been educated and trained professionally to specialise in this pedagogy. Indeed, a 2004 survey suggested that perhaps as few as half of all teachers teaching in the foundation phase had been trained to teach in this area (ELRC, 2005: 77). Until at least the mid-1990s, South African universities focused on training high school teachers, while leaving the training of primary school (including foundation phase) teachers to the since-rationalised - and in many instances poorer quality - provincial colleges of education. Only since 2001, and the concentration of all teacher education provision in the university sector, have good quality foundation phase teachers begun to be trained on a more consistent basis. Unfortunately, this otherwise positive trend is being negatively affected by the declining status of teaching as a profession, and, within that, by the perceived lower attractiveness of primary versus high school teaching qualifications: In 2005, an Human Sciences Research Council (HSRC) survey showed that only $16.5 \%$ of all Grade 12 intending student-teachers desired a primary education qualification, as opposed to $53.8 \%$ who wanted to get a secondary school qualification (Cosser, 2009: 87).

To intervene in teacher pre-service education seems to be a sensible option. Although we agree that community involvement and parent training are important in looking at young children's early formal education, the teachers are generally believed to hold the key to success, especially in low-income areas. De Witt (2008) notes that the

[...] backlog in terms of readiness for formal learning structures of children in low-income countries necessitates intervention programmes to alleviate the disadvantage.

In South Africa, the question must be asked: in what ways can interventions take place in order to strengthen foundation phase education provision to improve learning outcomes and minimise existing inequalities? Prinsloo and Bloch (1999) identify the

[...] language/s that young children use in school as they learn to read and write in a country where the hegemony of English is overwhelming, [...]

as one key issue that needs to be addressed. But there is no real way of addressing this if teacher education is not part of the strategy.

The McKinsey \& Co report (Mourshed \& Barber, 2007) noted that despite substantial increases in education spending in almost every OECD country, very few school systems achieved significant improvements in performance/quality of learning outcomes. The systems investigated in the McKinsey \& Co report are the exception. Some of the reforms that were initiated and which resulted in very little improvement include structural reforms, reducing class sizes, revising how schools were funded and/ or governed, curriculum reform and introducing systemic testing and assessments. The report points out that

[...] available evidence suggests that the main driver of the variation in student learning at school is the quality of the teachers (Mourshed and Barber, 2007: 12),

and that high-performing school systems consistently do three things well:

- $\quad$ They get the right people to become teachers. 
- They develop these people into effective instructors.

- $\quad$ They put in place systems and targeted support to ensure that every child is able to benefit from excellent instruction (Mourshed \& Barber, 2007: 13).

The provision of sufficient numbers of excellent teachers for the nation's foundation phase classrooms therefore appears to be one of the key strategic levers that South Africa could employ in order to improve learning outcomes in the foundation phase and beyond.

\section{An historical overview of new teacher provision in South Africa: 1994-2009}

Before we continue with the discussion on our research, we need to contextualise post-apartheid reform efforts in teacher provision. In 1994, according to the National Teacher Education Audit, some 26000 new teachers qualified from all teacher training institutions (Hofmeyr \& Hall 1995: 29). In the context of the time, these numbers were sufficient to lead the Audit to conclude not only that too many teachers, particularly primary school teachers, were being produced, but that many of them were also poorly trained (Hofmeyr \& Hall, 1995: 52, 81). A few years later Crouch and Perry (2003: 482) found that there were 20321 student-teachers enrolled fulltime at contact universities (implying that these were almost entirely newly-qualifying teachers, rather than existing teachers upgrading their qualifications) in 2001. Although these numbers look impressive, it is only upon closer analysis that it will be evident how few of these were studying for a foundation phase qualification. We will return to this point.

In 2004, an Education Labour Relations Council report estimated that approximately 9000 new teacher graduates were being produced annually, though of these at least 3000 were already practising teachers (ELRC, 2005: xvii), a figure quoted by the subsequent National Policy Framework for Teacher Education and Development (DoE, 2007: 10). A survey of approximately $10003^{\text {rd }}$ and $4^{\text {th }}$ year student-teachers in the system at the time indicated that only $25 \%$ of them were enrolled in classes that prepared them to teach primary school (ELRC, 2005: 65); by implication, only a fraction of this percentage were en route to becoming proper foundation phase teachers. The Environmental Labour Research Centre (ELRC) report also expressed concern about high drop-out levels at tertiary institutions (ELRC, 2005: 62); other studies have found that around one-third of teacher graduates do not plan to teach, at least not in South Africa (DoE, 2005: 51).

The picture does not appear to have changed significantly in the last few years. Kruss (2009: 6-7) found that, in 2007, some 33546 student teachers were enrolled in initial teacher education programmes across 22 universities, including about 9218 students at UNISA alone. At current estimated university graduation rates of between $18 \%$ and $25 \%$ (depending on whose statistics one uses: cf., for example, Letseka \& Maile, 2008: 2; DoE, 2010: 36), this still translates into more or less 6000 new teachers per year. In 2009 official estimates were only slightly higher, with the Department of 
Basic Education reckoning that between 6000 and 8000 teachers are graduating per annum (DBE 2009: 24).

Historical trends therefore show a significant decline in enrolments in initial teacher education programmes (Kruss, 2008: 190) and in graduates qualifying since 1994, though graduation numbers would seem to have stabilised since 2004 at least. However, while the studies described above have been able to point to overall enrolment and graduation patterns, they have not been able to disaggregate the figures to show enrolment and graduation patterns for specific phases of schooling, and for specific subjects. To improve all possible conditions for foundation phase teacher education, we need to know how many of the students were enrolled in the foundation phase programmes. This paper reports on a recent survey of teacher provision conducted to obtain more finely-grained data so that a clearer understanding of teacher provision, specific to particular school phases and subjects, can be achieved. The findings related to foundation phase teacher provision are portrayed here.

\section{Methodology}

Data was collected using an instrument designed to solicit 2009 pre-service teacher education information (enrolment and graduation patterns) from the public universities in South Africa that provide such programmes. The data received was scrutinised, discrepancies were queried, and the HEls were asked to verify the captured data. Twenty-two (22) HEls submitted information and 16 completed the verification process. The data obtained from universities in this manner was supplemented by audited data available on the Higher Education Management Information System (HEMIS) which is obtained through annual compulsory reporting of information by universities to the Department of Higher Education and Training. The data was analysed quantitatively, in order to answer the following questions:

- How many institutions offer foundation phase initial teacher education programmes?

- What were foundation phase initial teacher education enrolment and graduation patterns in 2009?

- How did the number of foundation phase teachers expected to graduate at the end of 2009 match the need for foundation phase teachers, on a national level, and on a provincial level, overall, and on the basis of language requirements?

\section{Findings}

In our analysis of the data it was affirmed that two qualification pathways are utilised to prepare new teachers, the four-year Bachelor of Education (B.Ed) degree or a relevant undergraduate degree (e.g. Bachelor of Science, Bachelor of Arts, etc.) followed by a one-year Post-Graduate Certificate in Education (PGCE). Twenty-one (21) public universities offer initial teacher education programmes, either the B.Ed, the PGCE or 
both. Only 13 of the 21 universities offered foundation phase initial teacher education programmes at the time.

Table 1: Numbers of new foundation phase teachers that were expected to graduate from 13 public HEls at the end of 2009

\begin{tabular}{|l|c|}
\hline \multicolumn{1}{|c|}{ Higher Education Institution } & Total \\
\hline Cape Peninsula University of Technology (CPUT) & 181 \\
\hline Nelson Mandela Metropolitan University (NMMU) & 33 \\
\hline North West University (NWU) & 177 \\
\hline Rhodes University (RU) & 12 \\
\hline University of Fort Hare (UFH) & 12 \\
\hline University of the Free State (UFS) & 72 \\
\hline University of KwaZulu-Natal (UKZN) & 126 \\
\hline University of Pretoria (UP) & 135 \\
\hline University of Stellenbosch (US) & 53 \\
\hline University of Venda (UNIVEN) & 19 \\
\hline University of the Witwatersrand (WITS) & 44 \\
\hline University of Zululand (UNIZULU) & 87 \\
\hline University of South Africa (UNISA)* & 324 \\
\hline Total & $\mathbf{1 2 7 5}$ \\
\hline
\end{tabular}

*UNISA 2009 figures were not provided, therefore figures are an estimate based on 2008 foundation phase graduates. Linear regression analysis was applied to the 2005-2008 number of graduates to estimate 2009 graduates. $29.1 \%$ of the qualifying graduates from UNISA are already employed in teaching posts.

In combination, in 2009, Table 1 shows that the 13 universities were expecting to graduate 1275 new foundation phase teachers.

In order to determine how this level of graduate output in 2009 matched expected demand for new foundation phase teachers in that year, several factors have had to be considered, and several data sources had to be drawn upon:

- The first factor concerns the attrition rate of teachers from teaching posts in public schools. Teacher attrition results from retirements (which is the single largest factor), resignations, terminations and death. Several reports (Hofmeyr \& Hall, 1995: 29; ELRC, 2005: xiii, 3, 7; DoE, 2007: 7; DBE, 2009: 22) have pointed to a relatively stable teacher attrition rate in the South African public schooling system of between $5 \%$ and $6 \%$. For the purposes of this analysis, a conservative attrition rate of $4 \%$ has been utilised, not taking into account the possible attrition due to the effect of HIV/AIDS.

- The second factor relates to the teacher-learner ratio in public schools. School Realities 2009 (DoE, 2009b: 4) sets this as 1:32.6 for state-paid teachers. It should 
be noted that this is a national ratio, across all phases of schooling, and that it is likely that the ratio in the foundation phase may be higher than this.

- Information about national and provincial learner enrolment in the foundation phase is drawn from School Realities 2009 (DoE, 2009b). These figures relate specifically to the number of learners enrolled in Grades R-3 in ordinary public schools.

- In order to estimate the number of African Language foundation phase teachers needed, South African population statistics were derived from Statistics in Brief 2004 (Stats SA, 2004). The African percentage of the population in each province was used to calculate the number and percentage of foundation phase teachers who should be able to teach in an African language.

These considerations allow foundation phase teacher provision to be matched with demand on a national level, as shown in Table 2 below:

Table 2: National foundation phase teacher provision and demand in 2009

\begin{tabular}{|c|c|c|c|}
\hline $\begin{array}{c}\text { Total national } \\
\text { Grade 1-3 } \\
\text { enrolment in 2009 }\end{array}$ & $\begin{array}{c}\text { Estimated number } \\
\text { of teachers (based } \\
\text { on average class } \\
\text { size of } \mathbf{3 2 . 6})\end{array}$ & $\begin{array}{c}\text { Number of foundation } \\
\text { phase teachers needed } \\
\text { in 2009 (based on } \\
\text { annual } 4 \% \text { attrition } \\
\text { rate) }\end{array}$ & $\begin{array}{c}\text { Number of } \\
\text { foundation } \\
\text { phase graduates } \\
\text { expected in } \\
\mathbf{2 0 0 9}\end{array}$ \\
\hline 3731874 & 114473 & 4579 & 1275 \\
\hline
\end{tabular}

There were 3617795 learners enrolled in Grades 1-3 in 2009. If a teacher-learner ratio of $1: 32.6$ is used, then 114473 teachers were employed as foundation phase teachers in public schools in 2009. Based on an annual attrition rate of $4 \%$, it could be expected that 4579 of these teachers would be lost to the system in 2009. While it is recognised that teacher supply happens in a variety of ways, including the reemployment of teachers who had previously left the profession, employment of unqualified people, and employment of foreign professionals, it is expected that in a stable system focussed on maintaining quality, the major source of new teachers would be well-qualified new graduates. This is certainly not the case in South Africa, with new teacher graduates providing just $27.8 \%$ of the estimated need for foundation phase teachers in 2009. There is a serious national shortage in the number of foundation phase teachers that are being produced.

While South Africa's Language in Education policy (DoE, 1997) does not specifically state that children must be taught in the mother-tongue at foundation phase level, the revised National Curriculum Statement Teacher's Guide document for the foundation phase (DoE, 2003C: 21-22) suggests that,

[...] wherever possible, learners' Home Language(s) should be used as the language for teaching, learning and assessment. This is particularly important in the foundation phase where children learn the basics of how to listen, speak, read and view, write, think and reason. 
The document goes on to suggest that where it is the case that all the learners in a class are of the same language group, then this language should be the language of learning and teaching. This scenario prevails in the majority of South African schools, especially the schools located in the rural areas. In urban areas, however, the situation is different.

The teacher provision system therefore needs to educate sufficient numbers of well-qualified teachers who are able to teach in the various languages spoken in the country. Table 3 provides the findings of an analysis to determine to what extent this is happening. The table shows a varied picture for the production of English language, Afrikaans language and for the various African language foundation phase teachers. The available data did not allow for differentiation between the various African languages.

For example, in the Eastern Cape Province, there were 727102 learners enrolled in the foundation phase in 2009. If a teacher-learner ratio of $1: 32.6$ is utilised, it can be estimated that there were 22303 active foundation phase teachers in 2009. If a $4 \%$ attrition rate is used, it could be expected that 892 of those teachers would leave the system in 2009, and so need to be replaced. In the Eastern Cape, $87.5 \%$ of the population are African language mother-tongue speakers, mostly isiXhosa. It could therefore be expected that of the 892 teachers that would be needed to replace those that were lost to the system in 2009, 781 of them should be African language speakers. On the supply side, three universities in the Eastern Cape produce foundation phase teachers (University of Fort Hare, Nelson Mandela Metropolitan University, and Rhodes University). In combination, the three universities expected to graduate 57 foundation phase teachers in 2009. Fifteen of the expected graduates were Afrikaans-speaking, 38 were English-speaking, and only four had an African language as mother-tongue.

The same logic was applied to an analysis of the information for the other provinces and the analysis showed that:

- Across all universities in the country, only 168 African language foundation phase graduates were expected in 2009. This must be squared up against the need to replace an estimated 3696 African language foundation phase teachers which the system would lose through attrition in that year.

- In every province this pattern is repeated, with the expected provision of new African language foundation phase teachers falling far short of the number lost due to attrition in the province.

- $\quad 73 \%$ of the African language foundation phase teachers were being produced in just one province, namely KwaZulu-Natal, the implication of this being that most of the African language graduates would have been isiZulu mother-tongue speakers. 


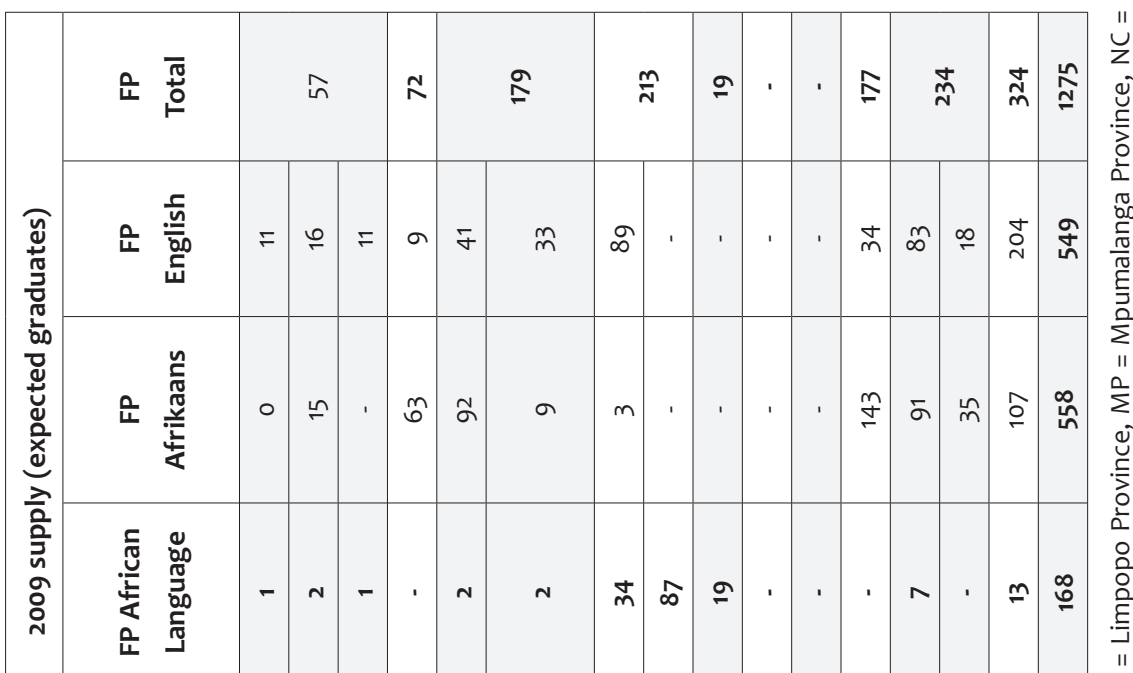

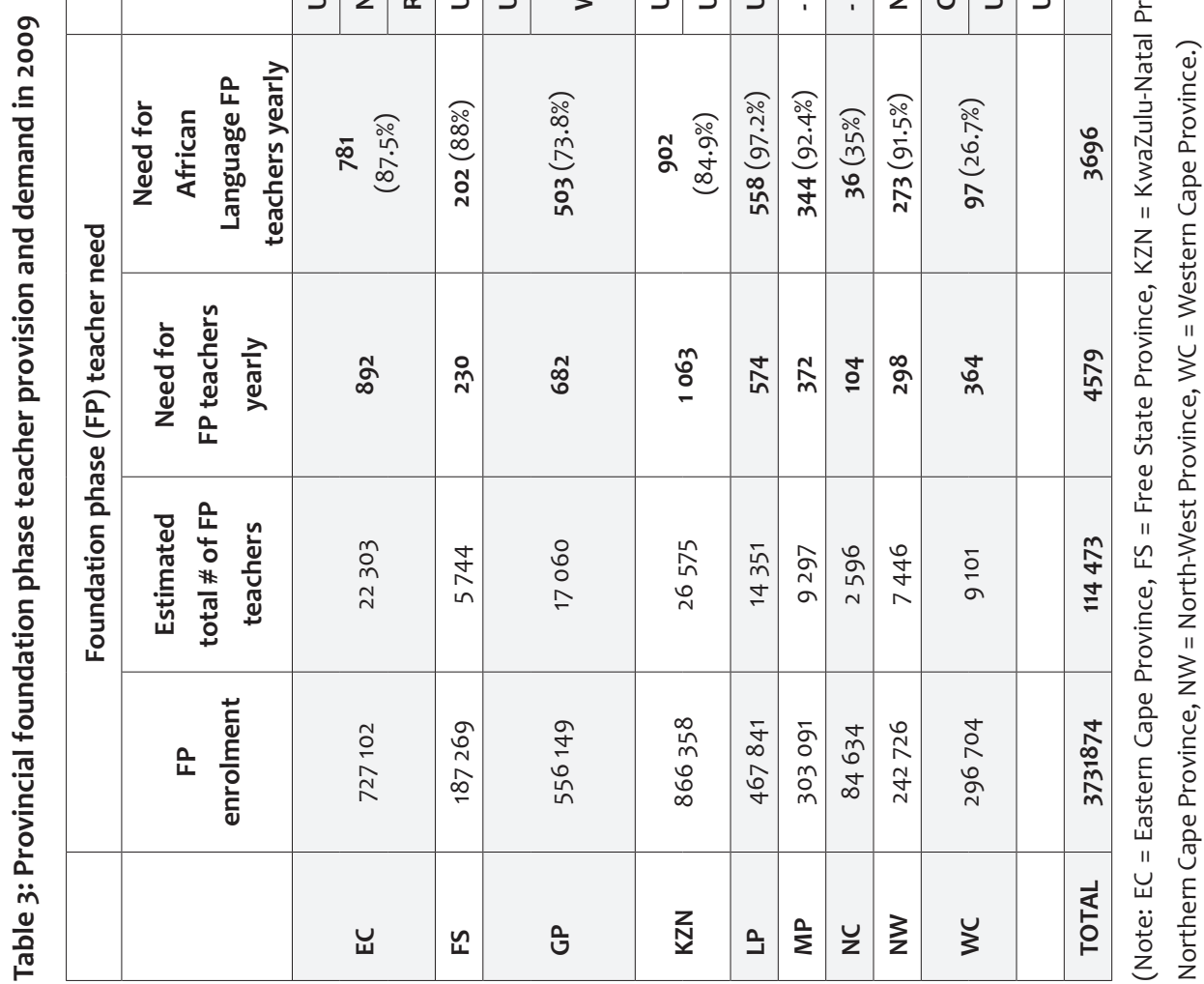

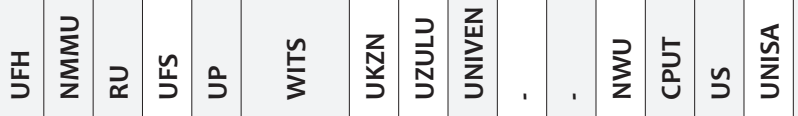


- $\quad$ UNISA can be considered to be a national provider of new teachers. However, even at UNISA, the expected number of African language graduates was extremely low ( 13 out of 324 graduates.)

\section{Discussion}

This investigation highlighted the large gap between the number of new teachers being produced by universities and the number of existing teachers who, due to resignations, death or retirement, need to be replaced every year. There is a clear imbalance between the graduate profile and the need for foundation phase teachers in 2009. There is also an urgent need for more African mother-tongue foundation phase teachers, highlighted by the fact that only $13 \%$ (168) of all the foundation phase teachers produced in 2009 were African mother-tongue speakers.

What exacerbates the implications of these findings that too few new foundation phase teachers are being educated at present, is the broader context that many current foundation phase teachers have not been trained in the area, and that many of those who have been trained have been poorly trained. The impact on learners is immense at this early stage of their schooling careers: studies have found that learners placed with high-performing teachers progress three times as fast as those placed with low-performing teachers, and that

[...] at the primary level, students that are placed with low-performing teachers for several years in a row suffer an educational loss which is largely irreversible (Mourshed \& Barber, 2007: 12).

Clearly, there needs to be a significant increase in the number of teachers that are being produced for the foundation phase, accompanied by an increase in the quality of teachers currently teaching in the foundation phase. Mourshed and Barber (2007: 16) also indicate at least one partial, possible way forward: we need to get "the right people" to become foundation phase teachers. The right people in this instance are the top third of school-leavers, for it is from this stratum that high-performing school systems generally recruit their teachers.

In South Africa's case, the right people are not only high-achieving learners, but also learners capable of teaching in an official language other than English or Afrikaans. Thus, if foundation phase teacher education is to be strengthened in order to more directly respond to the current shortfall, an integrated approach will need to be adopted. Such an approach, we suggest, should include:

- Improving the teaching and learning conditions in foundation phase classrooms through adequate resourcing.

- Counteracting what appears to be a strong negative image of foundation phase teaching, particularly amongst African language students, who appear highly reluctant to specialise in this phase of schooling, through strong recruitment and advocacy campaigns. 
- Enabling a clearly-defined career pathway for classroom-based foundation phase teachers, such as that being developed in the Draft Policy on the Minimum Requirements for Teacher Education Qualifications (DHET, 2010).

- Facilitating access of African language students, especially students from rural areas, to initial teacher education programmes, including through substantial ring-fenced bursary funding for top school achievers.

- Improving the status of foundation phase teacher education as a valued activity in universities through the development of a strong research community and research organisation which would engage in research to inform practice.

- Improving the relevance of foundation phase teacher education programmes, by developing research-informed foundation phase teacher education programmes to prepare African language foundation phase teachers.

All this is much easier said than done, of course. Adequate resourcing, and targeted bursary funding, are premised on government willingness and capacity to allocate yet more money to the education sector, or to determine which existing funds within or without the sector could be better allocated to the foundation phase. Defining career pathways, and insisting that all foundation phase teachers have a first degree, is likely to enhance the quality of foundation phase teaching, but getting all current teachers to this point requires negotiating numerous hurdles, such as

[...] the constraints of being an adult learner, lack of academic experience, possible language and cultural barriers, and the minimal wages that are standard in the field (Ackerman, 2005).

Improving the relevance, status and attractiveness of foundation phase teaching must perforce take into account similar difficulties which beset the field of Early Childhood Education, as well as the fact that too many ECD educators are insufficiently qualified or trained, and that ECD policies need to be better formulated, coordinated and monitored (HSRC, 2008).

But there is one thing which can be said without much prevarication: If the provision of sufficient numbers of quality foundation phase teachers is not achieved, it is likely that very little headway will be made in relation to improved Literacy and Numeracy levels at primary school level, and this will have a domino effect on learning and achievement at all levels of the system.

\section{References}

Ackerman, D. (2005). Getting teachers from here to there: examining issues related to an early care and education teacher policy. Early Childhood Research \& Practice, 7: 1.

Cosser, M. (2009). Studying ambitions: pathways from Grade 12 and the factors that shape them. Cape Town: HSRC Press. 
Crouch, L. \& Perry, H. (2003). Educators. Human resources development review, 2003. Pretoria: HSRC Press.

Department of Basic Education (DBE). (2009). National education human resources planning framework 2009/10-2013/14. Pretoria: DBE.

Department of Basic Education (DBE). (2010). Education for All (EFA) 2009 country report: South Africa. Pretoria: DBE.

Department of Education (DoE). (1997). Language in education policy. Pretoria: DoE.

Department of Education (DoE). (2003a). Systemic evaluation foundation phase mainstream report. Pretoria: DoE.

Department of Education (DoE). (2003b). Speech by the Minister of Education, Prof. Kader Asmal, MP, at the colloquium marking the launch of the foundation phase systemic evaluation report. Pretoria: DoE.

Department of Education (DoE). (2003C). Teacher's guide for the development of learning programmes: foundation phase. Pretoria: DoE.

Department of Education (DoE). (2005). Teachers for the future: meeting teacher shortages to achieve education for all. Pretoria: DoE.

Department of Education (DoE). (2007). National policy framework for teacher education and development. April 2007. Pretoria: DoE.

Department of Education (DoE). (2008). 2007 Grade 3 SE leaflet. Pretoria: DoE.

Department of Education (DoE). (2009a). Trends in education macro indicators report. Pretoria: DoE.

Department of Education (DoE). (2009b). School realities 2009. Pretoria: DoE.

Department of Education (DoE). (2010). Education statistics in South Africa 2008. Pretoria: DoE.

De Witt, M. (2008). The implementation of community-based care: a case study. Early Child Development and Care, 180(5): 1-14.

Department of Higher Education and Training (DHET). (2010). Draft policy on the minimum requirements for teacher education qualifications aligned with the higher education qualifications framework. Pretoria: DHET.

Environmental Labour Research Centre (ELRC). (2005). Educator supply and demand in the South African public education system. Cape Town: HSRC Press.

Hofmeyr, J. \& Hall, G. (1995). The national teacher education audit: synthesis report. Johannesburg: Edupol, National Business Initiative. 
Human Sciences Research Council (HSRC). (2008). Scaling up Early Childhood Development (ECD) (0-4 years) in South Africa: a review of training qualifications, training provision and training delivery in relation to the needs of the National Integrated Plan for ECD and the ECD component of the Expanded Public Works Programme. Pretoria: HSRC.

Kruss, G. (2008). Teacher education and institutional change in South Africa. Cape Town: HSRC Press.

Kruss, G. (2009). Introduction. In: G. Kruss (ed.), Opportunities and challenges for teacher education curriculum in South Africa. Cape Town: HSRC Press.

Letseka, M. \& Maile, S. (2008). High university drop-out rates: a threat to South Africa's future. Pretoria: HSRC.

Mourshed, M. \& Barber, M. (2007). How the world's best performing school systems come out on top. New York: McKinsey \& Company.

Prinsloo, M. \& Bloch, C. (1999). Children's early literacy learning: the mismatch between policy intention and teacher know-how. In: L. Chisholm (ed.), Critical perspectives in South African education: reconstituting the educational realm. Cape Town: Juta.

Statsistics South Africa. (2004). Statistics in Brief 2004. Pretoria: Stats SA.

United Nations Educational Scientific and Cultural Organisation (UNESCO). (2007). Strong foundations. Early childhood care and education. EFA global monitoring report. Paris: UNESCO. 